RAVI SOHAL

\title{
Working as a trainee in Australia: the essential steps before working out of programme
}

\section{SUMMARY}

This article outlines how trainees can work in Australia without disrupting their career plan and how this can be

\author{
accredited to their clinical training. In \\ particular, the processes involved in \\ obtaining approval for a post from \\ the Royal College of Psychiatrists, the
}

\author{
London Deanery, and the \\ Department of Immigration and \\ Medical Registration in Australia \\ are described in detail.
}

Just like many doctors in the UK, I had always wanted to work abroad after graduating from medical school. A medical degree has been described to me as a passport to the world, a means to experience different cultures and ways of life. However, the reality is that once you start working, you get drawn onto the career ladder of applying and working through training programmes and studying for specialist qualifications, and before you know it, the dream of working abroad remains just that, a dream.

In April 2006, I commenced training as a specialist registrar in the St Mary's higher psychiatric training scheme, London. The scheme maintained links with an area health service in Sydney, Australia, which meant it was possible to spend a year abroad as out of programme experience (more recently renamed out of programme experience in training). Out of programme experience in training or research allows a trainee to take 'time out' from the local training scheme, retaining their national trainee number and having the time count towards the award of the certificate of completion of specialist training

Several authors discuss working in and the structure of the Australian healthcare system, medical training and registration. ${ }^{1,2}$ However, the main challenge I found to working abroad was navigating through all the different forms, requirements and bureaucracies of both countries before I could actually start working. The whole process required significant time, effort and patience - in fact, I would suggest starting to plan 6 months ahead. I will attempt to simplify and describe the prerequisite steps for doctors considering working in Australia (Box 1).

\section{Get a job}

First, you will need to have some idea where and what (sub)specialty you would like to work in. If your UK training scheme has official links with other health services or training schemes from abroad, it is likely that they will also have details of who to liaise with. Otherwise, you may know of other doctors who have worked abroad or you could directly contact the directors of medical training themselves.

I wanted to gain further experience in forensic psychiatry, so I decided to apply for a position with Justice Health, which provides health services to inmates within the New South Wales criminal justice system. Justice Health provides services to correctional, detention and juvenile justice centres, and police cell and local court complexes covering the metropolitan, regional and remote areas of New South Wales. Trainees may work in a variety of settings, including maximum secure units and in acute, rehabilitation, addictions and adolescent psychiatry.

St Mary's higher psychiatric training scheme has links with the director of mental health in Sydney West Area Health Service, who visited London and had forwarded my interest to the statewide director for mental health at Justice Health. In addition, a consultant at my hospital had worked at Justice Health and was able to give me further details about the organisation and their experiences in Sydney.

After submitting my curriculum vitae to the director of registrar training at Long Bay Prison Hospital, I had a telephone interview and was offered a registrar position subject to references - but this was just the beginning.

\section{Get Royal College approval for the post}

Higher specialist training is supervised through the Royal College of Psychiatrists by Specialist Advisory Committees. Each specialty has its own committee, for example, general and old age psychiatry, and child and adolescent psychiatry. In order to have the registrar post in New South Wales recognised towards the certificate of completion of specialist training by the College, the following documents have to be submitted to the relevant committee:

- curriculum vitae;

- job description and timetable of the post, which should include at least $1 \mathrm{~h}$ of one-to-one supervision, and curriculum vitae of the proposed supervisor;

- written evidence of the post's approval status in Australia and evidence that the post is equivalent to a training position in the UK (a letter stating these points from the relevant health authority will suffice);

- letter of support from the organiser of the higher training scheme in the UK.

After reviewing these documents, the committee will then respond in writing as to whether they accept education \& training 
the out of programme experience as contributing to your certificate of completion of specialist training.

education \& training

\section{Get deanery approval for the post}

Information on how to gain approval from the dean is available on the postgraduate deaneries' websites. In the London Deanery this involves submitting:

- out of programme form, which can be downloaded from the deanery website (www. londondeanery.ac.uk/hospital-community-training/ specialties-contractual/out-of-programme) and has to be signed by the trainee, the educational supervisor and training programme director;

- supporting documentation: job description with timetable, and the written response from the College that confirms that the out of programme training can be accredited to clinical training for the certificate of completion of training.

Following the recent changes in postgraduate medical training, since September 2007 all deaneries are required to forward the above documentation to the postgraduate medical education and training board (Box 2), to gain prospective approval for the placement.

\section{Get a visa}

To obtain immigration approval, it is important to liaise with the organisation you plan to work for and the Australian High Commission in London (Box 2). I applied for the occupational trainee visa (Subclass 442) which is a temporary visa valid for up to 2 years to undertake structured and supervised workplace-based training (www.immi.gov.au/students/sponsored/otv/index.htm). Justice Health acted as the nominating organisation and initially lodged a nomination with the Department of Immigration and Citizenship (Australia). Once the nomination is approved, an application for a temporary residence visa (form 147) can be downloaded from the Department of Immigration and Citizenship website and completed. In addition to the application form, copies of degrees and professional qualifications should also be sent. The application charge in 2007 was $\mathrm{f} 80$.

After approximately 2 weeks, the Australian High Commission will email and request that you undergo medical and X-ray examinations by panel doctors and radiologists designated by the Australian government. This includes HIV, hepatitis B and hepatitis C blood tests and completion of forms 26 (medical examination for an Australian visa) and 160 (radiological report on chest X-ray of an applicant for an Australian visa), which are returned directly by the panel doctor to the Australian High Commission. The approximate cost of the medical and $\mathrm{X}$-ray examinations was $\mathrm{f} 230$. Following the medical examination, the trainee should forward their passport to the Australian High Commission, who will grant the visa.

The Department of Immigration and Citizenship will also allow your spouse and any dependent children to apply for a visa in the same subclass. Family members on the occupational trainee visa may only work up to $20 \mathrm{~h}$
Box 1. Summary of pre-requisite steps

1. Find an appropriate training post through your training scheme or an Australian health service

2. Obtain recognition of the post as contributing to your Royal College of Psychiatrists certificate of completion of specialist training

3. Obtain approval for the post from your deanery and postgraduate medical education and training board

4. Apply for immigration approval

5. Submit documents for primary source verification to EICS

6. Apply for medical registration with the state medical board

per week. If any family member is considering working more than that, then other visa subclasses should be considered, for example the working holiday visa (Subclass 417).

\section{Get primary source verification of your qualifications}

In 2005, a medical scandal was uncovered in Queensland involving a surgeon subsequently nicknamed 'Dr Death', and allegations linking him with the death of at least 87 patients. His employers in Queensland had failed to check his past experience and qualifications, in particular restrictions and revocation of his licence to practise in the USA from 1998 and 2001. Consequently, the Australian state/territory medical boards introduced major changes to the medical registration of international medical graduates. A mandatory prerequisite step to registration now involves primary source verification of documents such as medical school certificates, specialist qualifications and medical registration certificates issued by other jurisdictions. Primary source verification is obtained by the Educational Commission for Foreign Medical Graduates (ECFMG) International Credentials Services (EICS), based in the USA. The application form contains an affidavit and release that has to be certified by a notary public, first-class magistrate or consular official.

The process is coordinated by the Australian Medical Council (Box 2), on behalf of the state/territory medical boards, which forwards the documents to EICS (www.ecfmg.org/eics/index.html). The application fee in 2007 was AU\$175. The applicant is then issued a letter and receipt by the Australian Medical Council and later an identification number by EICS. The New South Wales

\section{Box 2. Further information}

- PMETB guidance on out of programme training/research (www.pmetb.org.uk/index.php?id=873)

- Australian Government Department of Immigration and Citizenship information on visas and immigration (www.immi.gov.au/immigration.htm)

- Australian High Commission, panel doctors and radiologists (www.uk.embassy.gov.au/lhlh/health.html)

- Medical registration with Australian Medical Council (www.amc.org.au/index.php/img/ver/129-psvmb) 
Medical Board will accept the letter from the Australian Medical Council or documentation issued by EICS confirming your EICS identification number as evidence that this process of primary source verification has commenced, which may take a further 3 months to complete.

\section{Get medical registration}

There are several categories of registration in the different Australian states and territories, based on a doctor's primary medical qualification and subsequent Australian qualifications. International medical graduates in New South Wales are usually granted conditional registration.

In order to register, the New South Wales Medical Board's international medical graduates' application form (www.nswmb.org.au/index.pl?page $=152$ NSWMB) and the following documents must be submitted in person at the Board's office:

- proof of identity;

- primary medical degree and specialist qualification (original documents or certified copies only);

- certificate of good standing which must be issued within the previous 3 months by the General Medical Council and sent directly to the New South Wales Medical Board:

- evidence of English language proficiency (English GCSE certificate or equivalent qualification);

- current curriculum vitae;

- references should be provided by persons who have known you for at least 12 months and are not family members:
Box 3. Costs accurate at time of application in 2007

Application fee for occupational trainee visa

Medical and X-ray examinations fee

About $\mathrm{f} 230$

EICS application fee

AU\$175

New South Wales Medical Board application fee

AU $\$ 220$

New South Wales Medical Board registration fee

$\operatorname{AU} \$ 270$

- evidence that primary source verification of documents by EICS is in process (see pp. 194-195).

In addition, there is an application fee of AU $\$ 220$ and a registration fee of $A \cup \$ 270$ (Box 3).

This is the end of the road in terms of completing all the steps required to practice medicine in New South Wales. A few weeks after submission of the above documents, the New South Wales Medical Board will provide written confirmation that conditional registration has been granted for a period of 12 months. It is now time to enjoy and make the most of your learning opportunities in a different health system and culture. Good luck!

\section{References}

$\begin{array}{ll}1 \text { Kisely S, Jones J. Working in } & 2 \text { Ruffer A. A bedside account of } \\ \text { Australia (career focus). BMJ1999; } & \text { working in Australia. BMJ Career } \\ \text { 318: 2a. } & \text { Focus, 2002; 324: S187. }\end{array}$

Ravi Sohal Specialist Registrar in General Adult Psychiatry, West London Mental HealthTrust, Uxbridge Road, Southall, Middlesex UB1 3EU, email: dr.ravi@doctors.org.uk 